\title{
The Production of the Muselmann and the Singularity of Auschwitz: A Critique of Adriana Cavarero's Account of the "Auschwitz Event"
}

\author{
Leonhard Riep \\ Universität Leipzig, Institut für Philosophie, Beethovenstraße 15, 04107 Leipzig, Germany \\ Corresponding author. leonhard.riep@gmail.com
}

(Received 19 September 2019; revised 26 March 2020; accepted 15 April 2020)

\begin{abstract}
Feminist philosopher Adriana Cavarero claims in her book Horrorism: Naming Contemporary Violence that the core of the horror of Auschwitz is constituted by the figure of the Muselmann. I argue that Cavarero's lack of an accurate historical engagement with this figure in particular and with Auschwitz in general leads her to a speculative turn, thereby universalizing the phenomenon of the Muselmann by making it the example of Auschwitz, and moreover, the key factor to explain its singularity. I show that the phenomenon of the Muselmann, although a particular horrible effect of Auschwitz, is not limited to this concentration and extermination camp system. Consequently, the characteristic that makes Auschwitz a unicum cannot be found in the Muselmann. Rather, as I elucidate, the singularity of Auschwitz and the Shoah in general must be understood in relation to the true goal of this camp: the final extermination of European Jewry.
\end{abstract}

In Horrorism: Naming Contemporary Violence and in "Destroy Your Sight with a New Gorgon': Mass Atrocity and the Phenomenology of Horror” (Cavarero 2009; 2018), Adriana Cavarero tries not only to analyze the specific structure of horror, but also to give an account of a particular horrible event: "Any present-day reflection on horror must, sooner or later, come to terms with Auschwitz" (Cavarero 2009, 34). Cavarero approaches the horror of Auschwitz primarily by means of an interpretation of Primo Levi's The Drowned and the Saved and Hannah Arendt's The Origins of Totalitarianism (Arendt 1979; Levi 1988), arguing that "the true purpose of the violent machinery of the Nazi Lager" (Cavarero 2009, 37) was not the extermination itself but an exceptional ontological crime: the planned and methodically conducted production of living corpses who suffered from severe starvation and exhaustion to the point of a total apathy toward their own deaths. In the camp language of Auschwitz, these dehumanized prisoners were called Muselmänner-a phenomenon that has recently been much discussed in philosophy. ${ }^{1}$

Throughout this article, I will argue that Cavarero's concentration on the Muselmann as the decisive factor to explain the horror of the "Auschwitz event" and,

(c) The Author(s), 2020. Published by Cambridge University Press on behalf of Hypatia, a Nonprofit Corporation. This is an Open Access article, distributed under the terms of the Creative Commons Attribution licence (http://creativecommons. $\mathrm{org} /$ licenses/by/4.0/), which permits unrestricted re-use, distribution, and reproduction in any medium, provided the original work is properly cited. 
moreover, its singularity, cannot be maintained. To support this claim, I will proceed in four steps. First, I will introduce the category of horror in connection to Cavarero's project of a "relational ontology of uniqueness" with special attention to her understanding of vulnerability. Proceeding from this, in the second step, I will critically analyze her reflections on the Muselmann as the particular example of the horror of Auschwitz. The leading question will be how Cavarero defines the singularity of Auschwitz. Third, I will engage with Cavarero's claim that the horror of Auschwitz exceeds a historical account. My suggestion, however, is that Cavarero's lack of an accurate historical engagement with the phenomenon of the Muselmann in particular and with Auschwitz in general leads her to a speculative turn, thereby universalizing the phenomenon of the Muselmann by making it the example of Auschwitz, and moreover, the key factor to explain its singularity. In the last step, I will show why this is problematic: Here I will argue that the phenomenon of the Muselmann, although a particular horrible effect of Auschwitz, is not limited to this concentration and extermination camp system. Consequently, the characteristic that makes Auschwitz a unicum cannot be found in the Muselmann. Rather, against Cavarero, who explicitly rejects this explanation, the singularity of Auschwitz must be understood in relation to the true goal of this camp: the final extermination of the Jews.

\section{The Category of Horror and Cavarero's "Relational Ontology of Uniqueness"}

In Horrorism, Cavarero gives an account of a specific phenomenon of contemporary violence, which she describes in distinction to terrorism as "horrorism." The objective of this neologism is to shift the focus from the perpetrators of violence to the helpless victims (Cavarero 2009, 3) and to provide "a conceptual framework for distinctive scenarios where unilateral violence is perpetrated on defenseless victims through specific modalities of destruction that target the human as human" (Cavarero 2018, 125). In her etymologically inspired interpretation of terror and horror, Cavarero traces the former to the phenomenon of fear and the attempt to escape the inflicted violence (Cavarero 2009, 4-6), whereas the latter constitutes a violence that blocks any motion. In accordance with this freezing effect, Cavarero associates the phenomenon of horror with the Greek mythological figure of Medusa, the female Gorgon who turned those who looked at her into stone (3). The horror has a paralyzing impact precisely because it is related to the phenomenon of repugnance rather than to that of fear (7-9; Cavarero 2018, 126-27). This repugnant character indicates, in turn, a particularly excessive form of violence, which does not exhaust itself in the act of killing, as Cavarero emphasizes:

As its corporeal symptoms testify, the physics of horror has nothing to do with the instinctive reaction to the threat of death. It has rather to do with instinctive disgust for a violence that, not content merely to kill because killing would be too little, aims to destroy the uniqueness of the body, tearing at its constitutive vulnerability. What is at stake is not the end of a human life but the human condition itself, as incarnated in the singularity of vulnerable bodies. (Cavarero 2009, 8)

Hence, the term horrorism signifies a kind of violence that is distinguished from ordinary forms of violence such as homicide, insofar as the former aims at the human condition itself. This violence is not only unbearable to watch, but also paralyzes the human being in light of the abomination it has to witness.

The "horroristic" violence attacks, as Cavarero writes, the human condition as such by targeting the uniqueness of the body and its constitutive vulnerability. This calls 
attention to the basic ontological categories of her philosophical, and decidedly political and feminist, project (Cavarero 1991, 181-82; 2002, 519-20; Cavarero and Bertolino $2008,134)$, which she derives from Luce Irigaray's "philosophy of sexual difference" (Cavarero 1995, 6) ${ }^{2}$ and an elaborate involvement with Hannah Arendt's work (Cavarero and Bertolino 2008, 147). Indebted to Arendt's understanding of the human condition as fundamentally plural- "to the fact that men, not Man, live on the earth and inhabit the world" (Arendt 1998, 7)-Cavarero describes her own "philosophical frame" as a "relational ontology" (Cavarero 2016, 10), contrasting it to the individualistic ontologies of the philosophical tradition. This relationality is not, as Cavarero specifies, an abstract category, but grounded in the materiality of the human body: "it is a corporeal relationality, precisely where corporeality exists in singularity" (Cavarero and Bertolino 2008, 155). Equally central for her "relational model" (Cavarero 2016, 11) is thus the category of uniqueness, which, still in accordance with Arendt, is not contradictory to the human condition of plurality, but constitutive of it. Uniqueness is the prerequisite for plurality, because it "makes of everyone a being that is different from all the others" (Cavarero 2005, 3). Therefore, Cavarero defines her project also in terms of an "ontology of uniqueness" (Cavarero and Bertolino 2008, 137). In her account, uniqueness and relationality are intertwined ontological categories, which are constitutive of the human condition as such.

It is important to note, however, that Cavarero is not consistent in her terminological use of "human nature" and "human condition": Sometimes she is making a connection between ontology and "human nature," for example when she is writing that in Auschwitz "it is human nature-in other words, the ontological plane directly-that is concerned" (Cavarero 2009, 41), and that only in this Nazi Lager "it was possible to manipulate human nature" (Cavarero 2009, 42). At other times she is connecting ontology with the "human condition," for instance when she claims that "the very significance of 'death' and 'life' are decided on an ontological criterion. Extreme horror, for Arendt, has to do with the human condition as such" (43). Nevertheless, it seems that Cavarero is using "human condition" mostly in connection to "vulnerability" $(8,21,30$, $38,103)$, which is in turn based on the ontological categories of relationality and uniqueness. The latter could therefore be interpreted as the ontological dimensions that constitute "human nature," whereas "the human condition of vulnerability" would be the result of these dimensions of "human nature" (103). According to this interpretation, singular human beings are not only uniquely embodied, but at the same time embedded in a web of relations with other unique human beings, thereby exposing themselves to the other(s).

Furthermore, and as a direct consequence of the exposure that is inscribed into the relational uniqueness, the human being is simultaneously exposed to the twofold "condition of vulnerability: wounding and caring" (20). Both comportments are always possible when, as Cavarero explains still in reference to Arendt, unique human beings expose themselves to the other(s). For Cavarero, this "constitutive vulnerability" (20) is connected to the scene of birth: "The vulnerable being is here the absolutely exposed and helpless one who is awaiting care and has no means to defend itself against wounding" (21). In other words, only in the "primary scene" (Cavarero 2016, 13), as she calls it in Inclinations, are vulnerability and defenselessness congruent, although vulnerability is a lifelong and fundamental trait of human existence. What distinguishes the vulnerability of the adult from that of the infant is precisely the extent-or rather the form-of helplessness, which in the case of the infant is not only naturally absolute, but also coalesced with vulnerability. 
Cavarero's "relational ontology of uniqueness" - to combine both of the characterizations of her ontological project-forms the background of her account of horror as violence that aims at the human condition as such. Since horroristic violence destroys human uniqueness and relationality, and therefore touches "the ontological plane directly" (Cavarero 2009, 40), she defines this violence as an "ontological crime" (16). Throughout the book, Cavarero analyzes several examples of contemporary ontological crimes, such as torture or suicide bombings. However, she characterizes the destruction of the uniqueness of the body, which she designates as the origin of repugnance, as a "disfigurement" (Cavarero 2018, 131) and not necessarily as a literal tearing apart of bodily unity, although the latter can be one example of horroristic violence. Ann V. Murphy therefore defines ontological crime correctly as violence "that undoes the very integrity of the body, that eviscerates the figural unity that renders a human body recognizable as such" (Murphy 2011, 585).

Notably, Auschwitz has a special position in the list of ontological crimes. It represents, as Cavarero highlights, an extraordinary example of such crimes in the history of the twentieth century: "For many reasons, what has been called the 'Auschwitz event' nevertheless remains an emblematic case and, as is often said, a unicum" (Cavarero 2009, 34). In the following, I will analyze her interpretation of Auschwitz in light of the category of horror, specifically relating her deliberations on Levi and Arendt to the already outlined fundamental ontological categories of relationality and uniqueness, as well as to constitutive vulnerability. Cavarero's argument that Auschwitz is a unicum will be especially important.

\section{The Horror of Auschwitz and the Production of the Muselmann}

Asking how to come to terms with the unicum of Auschwitz, with this "apex of Horrorism" (Cavarero 2009, 33), Cavarero proceeds in two steps: first, by dealing with Levi, second, by discussing Arendt. The first step is centered around the question of relationality, and the second focuses on uniqueness. Binding the two steps together, the question of (in)vulnerability functions as Cavarero's central category to explain the unicum of Auschwitz.

As already noted, Medusa symbolizes the paralyzing effect of horror. The figure of the Gorgon is the leitmotif that opens Horrorism wherein Cavarero takes up the Auschwitz event. In a later chapter, titled "Those Who Have Seen the Gorgon," Cavarero discusses primarily Levi's The Drowned and the Saved, in which he describes the Muselmänner as "those who saw the Gorgon" (Levi 1988, 83-84, cited in Cavarero 2009, 34). In accordance with her understanding that horror is aimed at the destruction of the ontological, Cavarero notes that the horroristic violence of the Nazi Lager transgresses not only "simple homicide" (34), but also the usual form of horror, which inflicts "unilateral violence" (36) on the helpless victim:

In contrast, what lies at the core of the Lager system is a less straightforward violence, one more perversely productive: by means of experiments that surpass in their savagery the known range of cruelty, it is essentially aimed at fabricating a victim, insensitive by now to the vulnus, in whom the human dignity of the defenseless degenerates into a caricature of itself. (36)

For Cavarero, Muselmänner, who are in a state of helplessness that is both artificial and degenerative precisely because they are not able to sense the violence inflicted on them, 
become the typical example of the horror of Auschwitz. According to Cavarero, the deeper meaning of "death camp" refers thus not only to the extermination itself, but to the production of totally "helpless beings paradoxically no longer vulnerable" (34).

Cavarero emphasizes that the Muselmann was not-as the figure of the Gorgon might suggest-a sudden effect of partially occurring violence, but the result of "a long and systematic process of dehumanization" (Cavarero 2018, 133). One of the central aspects of this process was the continuous transformation of prisoners into isolated beings, usually by letting them suffer from malnutrition. This ongoing process resulted in a-for Cavarero, artificially produced-Hobbesian "state of nature," in which the prisoners had to fight with one another for food and survival, thereby "nullifying any possible relations among them" (Cavarero 2009, 38). The production of the Muselmann therefore has isolation as a prerequisite, which leads eventually to the destruction of the relational dimension of the human condition.

In connection with the isolated and helpless but no longer vulnerable Muselmann, a crucial distinction comes into play, which was already implied in the discussion of Cavarero's central ontological categories: "the conceptual distinction . . . between vulnerability and helplessness" (Söderbäck 2018, 284). The helplessness of an adult is, as Fanny Söderbäck points out with recourse to Horrorism, different from that of an infant:

If both birth and violence have in common a fundamentally asymmetrical structure, the crucial difference between them, in other words, is that the former is rooted in vulnerability and relationality (conditions of possibility for human uniqueness), while the latter is marked by helplessness and loneliness (the destruction of human uniqueness and the rendering of singular individuals into superfluous victims). (284)

Applied to the case of the Muselmann, this means that whereas the helplessness of the infant is total insofar as it is naturally one and the same with vulnerability, the total helplessness of the Muselmann has to be produced artificially, precisely by turning the constitutive vulnerability into "[i]nvulnerability" (Cavarero 2009, 35), thus separating vulnerability from helplessness and totalizing the latter. For Cavarero, this distinction seems to be the central point when she argues that infants and small children were usually killed immediately in Auschwitz, because "the methodical fabrication ... would have been superfluous in the case of children, given that they are the helpless by definition" (36). The production of the helpless and simultaneously invulnerable Muselmann, to sum up Cavarero's main claim throughout this chapter of Horrorism, constitutes not only an extraordinary ontological crime targeting the ontological dimension of relationality with its concomitant vulnerability but designates, moreover, "the true purpose of the violent machinery of the Nazi Lager" (37).

The centrality of the figure of the Muselmann for Cavarero's understanding of the "Auschwitz event" is further confirmed when she subsequently turns to Arendt's Origins of Totalitarianism. In accordance with her interpretation of Levi, Cavarero's reading of Arendt stresses that the horror of Auschwitz constitutes not a simple, but "extreme form" (42) of horror, since the horror of the extermination camp-and here Cavarero cites Arendt directly-“stands outside of life and death" (Arendt 1966, 444, cited in Cavarero 2009, 42). In reference to the production of the Muselmann, Cavarero points out that "on this point the accord between Levi and Arendt is perfect" (42): Both perceive the Nazi Lagers not as a simple means to kill but as a methodically 
refined experiment that ultimately aims for fabricating "those who, albeit still alive, are already dead because in them the essential boundary between living and dying has been erased" (42). The horroristic violence of Auschwitz poses an ontological problem because it tries to alter and ultimately destroy the "ontological material" (43). Cavarero thus claims, quoting Arendt directly, that "[i]n the Nazi concentration-camp system, 'suffering, of which there has always been too much on earth, is not the issue, nor is the number of victims. Human nature as such is at stake"' (Arendt 1966, 458-59, cited in Cavarero 2009, 40).

Besides the crucial similarity between Levi and Arendt, what comes into view throughout this chapter is a change of emphasis: Whereas the chapter on Levi was centered around relationality, the one on Arendt is concerned mostly with the question of uniqueness. The production of the Muselmann is not analyzed here primarily as a violent process of isolation that attacks the relational dimension of the human conditionin turn leading to a state of invulnerability-but as a transformation of "unique beings into a mass of superfluous beings" (43) that robs them of their "unpredictability and spontaneity" (45). In relation to Arendt it can thus be said that at the core of Auschwitz lies "the killing of uniqueness as primary ontological crime" (43-44). Although Cavarero acknowledges the centrality of the ontological attack on uniqueness, she nonetheless criticizes Arendt's Origins of Totalitarianism for not considering-as Levi does emphatically-the fundamental vulnerability that, according to Cavarero, is at stake:

The helpless one stands at the center of the scene, indeed he shows all the signs of his atrocious perversion by the concentration-camp machinery, but he does not rise explicitly to the status of criterion of horror. In this sense, in his comprehension of the horrorism of which Auschwitz constitutes the unrivaled paradigm, Levi goes further than Arendt. (46)

The ontological crime committed in Auschwitz is therefore an extraordinary one; it constitutes an "extreme, unprecedented, exorbitant horror" (39). Moreover, what makes Auschwitz a unicum is precisely the perverse fabrication of the helpless but no longer vulnerable-and therefore inhuman-being:

If Auschwitz is a unicum in the long history of human barbarity, if the task of bearing witness to this "Medusa-faced truth" creates a sort of reluctance, that is because ontological crime has here revealed unilateral violence against the helpless to be its decisive criterion. Indeed, through its artificial fabrication of this helpless being - a degenerated helpless one, no longer vulnerable-it has revealed it from the side of the inhuman, of excess. (39)

The production of the Muselmann is not only an extraordinary ontological crime but also the criterion that makes Auschwitz a unicum. With her shift of perspective away from the perpetrators toward the victims, Cavarero is able to bring to light a phenomenon that affected the everyday experience of thousands of prisoners of Auschwitz.

At the same time, her account leads to a problem: Although Cavarero notes that " $[t]$ he peculiarity of the horror of the extermination camp lies in the methodical process of annihilation, including the mass production of corpses and the problem of their elimination" (Cavarero 2018, 138), she simultaneously prioritizes the production of the Muselmann over the extermination itself, claiming that the former represents the 
"core of the Lager system" (Cavarero 2009, 36), whereas the latter-as the already mentioned example of the direct killing of the children shows-is not understood as genuine horroristic violence. Cavarero's understanding of horror therefore has the tendency to conceal-or rather, exclude-the mass extermination itself. However, it is questionable whether the horror of horrorism, which Cavarero defines as a destruction of the ontological plane realized through the production of the Muselmann, adequately describes the crucial dimensions of the horror of Auschwitz. In other words, the problem is that "[n]o analysis of [the horror of Auschwitz] that cannot account for the extermination of European Jewry is fully adequate" (Postone 1986, 303). ${ }^{3}$

\section{Historical Account and Speculative Philosophy}

Before I address this issue, I have to discuss a point that Cavarero makes prominently in "Destroy Your Sight with a New Gorgon"': namely, that the horror of Auschwitz was so excessive that it "de[fies] any and all historiographic or sociological classification" (Cavarero 2018, 124). Relating her claim to Arendt's Origins of Totalitarianism, Cavarero argues: "[O]ur attempt to understand must necessarily grapple with the historical context in which the Auschwitz event comes into being, an event whose horror, however, surpasses and exceeds any historical justification or explanation, including anti-Semitism (129). What Cavarero tries to establish is an account that thinks the horror of Auschwitz in ontological terms rather than politico-ideological, socioeconomic, or historical ones. Since "every attempt to make sense of its horror runs into a limit of explicability" (130), Cavarero offers an approach that centers around the emotional effect of repugnance that horror produces, an emotion that literally leaves witnesses speechless when faced with excessive and senseless violence.

Her account, which is not concerned with a historical explanation, can thus be read in light of "the method of exaggeration" (Cavarero 2016, 10), as Cavarero marks her own approach in Inclinations, borrowing this description from Hans Jonas's characterization of Arendt's philosophy. This methodology, for instance, would explain her partial misrepresentation of Arendt's argument in The Origins of Totalitarianism that "human nature as such is at stake" in concentration camps, the latter portrayed by Cavarero as referring solely to Nazi Lagers. As already shown, the use of this argument leads to Cavarero's main claim that the core of Auschwitz-and hence its status as unicum-is related to an attack on the ontological material itself. That Arendt at the point in question is not limiting the characterization that "human nature as such is at stake" to Nazi camps, but is using it in reference to modern concentration-camp systems in general, that is, to a generic sense of the term concentration camp entailing those of "[t]he Nazis and the Bolsheviks" (Arendt 1979, 459; emphasis added), is lost in Cavarero's account. What Cavarero instead highlights with this reference to Arendt is that the Muselmann is not only the paradigm of horrorism but also the example, which makes Auschwitz a unicum. Considering that the ontological material was not only targeted, as Arendt obviously argues, in the Nazi Lager system, but also in the Gulag Archipelago, how can Cavarero's claim maintain that Auschwitz is a unicum because an ontological crime, symbolized in the figure of the Muselmann, had its apex here? In other words, can the Muselmann really function as the decisive factor to explain the unicum of Auschwitz? What this problematization already shows is the danger of the absence of a historical perspective in politico-theoretical thought and philosophico-ontological considerations, an absence that can lead to the overestimation and universalization of a peculiar phenomenon (such as the Muselmann), although 
one's own approach claims to avoid universalizations of this kind as a matter of principle (Cavarero, 2002, 514, 520, 524). Consequently, I would argue that an ontological perspective has to be mediated with a historical analysis in order to avoid the universalization of a peculiarity, and vice versa.

It is likely that Cavarero is aware of the previously mentioned misquotation. In relation to a crucial citation in The Human Condition-a quote from a passage of the Bible, in which the Gospels announce, according to Arendt, that "A child has been born unto us" (Arendt 1998, 247)—Cavarero writes: "That Arendt frequently cites from memory, and that the citations tend to be bibliographically incorrect, is known to her interpreters, but in this case the error ends up being quite significant" (Cavarero 2014, 13). The same could be said about Cavarero, with the difference that Arendt is misquoting a text, which cannot be considered a source-based, historiographical account according to modern scientific criteria, whereas Cavarero's misquotation of Arendt's historical investigation leads, as I will argue in the following, to a misrepresentation of historical facticity. In this particular case, Cavarero's method of exaggeration thus makes a speculative turn. This is rather paradoxical, since it is not only in contradiction to certain historical circumstances, but leads simultaneously to a universalization that Cavarero tries to prevent in Horrorism, on the one hand, by bearing witness to Shoah survivors like Levi, and, on the other, by focusing on the ontological dimension of uniqueness.

In what follows, I do not want to contest the claim that the phenomenon that Cavarero defines as horror, and the repugnance it produces, exceed a historical explanation. Certainly, the unwatchable and unspeakable horror of Auschwitz pushed the boundaries of (historical) rationality and produced repugnance. However, taking Cavarero's own statement seriously that the historical context is at the very least vital for grasping the emergence of a horroristic project such as Auschwitz, I will contest her claim that the Muselmann represents the core of the Nazi camp. What is first and foremost at stake is not so much the validity or reasonability of a historical judgment or explanation, but rather historical facticity itself.

Having said that, I explicitly do not claim that historical facts and circumstances are outside of discursive orders, that is, that they would speak for themselves without the effort of-always contestable-interpretations. Rather, I want to highlight that philosophical and politico-theoretical approaches have to consider historical analyses, precisely because historical sources have, as Reinhart Koselleck argues, a "power of veto" (Vetorecht), which "forbid[s] us to venture or admit interpretations that can be shown on the basis of a source to be false or unreliable. False data, false statistics, false explanation of motives, false analyses of consciousness: all this and much more can be revealed by source criticism" (Koselleck 2004, 151). Consequently, although I agree with Cavarero that a historical perspective cannot offer a complete explanation of horroristic effects like repugnance, nevertheless, a historical account must be an integral part of any analysis of Auschwitz.

\section{The Muselmann and the Question of the Singularity of Auschwitz}

Why is it problematic to conceive the Muselmann as the typical example of Auschwitz, moreover, as the core of Auschwitz that makes it a unicum? Two points are particularly important: On the one hand, it leads to a depiction of Auschwitz in which the Muselmann is: (a) a phenomenon that is historically limited to the Nazi Lager system, and (b) the common final state of almost all adults who were deported to Auschwitz. 
Moreover, I will argue that the concentration on the Muselmann tends to detract attention from the actual purpose of the extermination camps, which Nazi jargon euphemistically called the "Final Solution of the Jewish Question." Certainly horrific, the unicum of Auschwitz is not constituted by horror as Cavarero defines it, but rather by the "horroristic" anti-Semitic vision of the final destruction of the Jews in a methodical and to a large extent industrial manner. Although its horroristic effects exceed a historical explanation, its emergence has to be grasped nonetheless in light of this specific form of anti-Semitism.

I understand the "Auschwitz event" and the discussion about the singularity of Auschwitz as a reference to the Shoah in general, but it does not become clear in Cavarero's reflections whether she refers to Auschwitz as a particular concentration and death camp or employs "Auschwitz" as a terminological substitution for the Shoah. That Cavarero speaks several times of the "Auschwitz event" can be seen as an indication that she uses "Auschwitz" as a synecdoche. It is likely that she is referencing, when using this term, the Italian Arendt scholar Paola Helzel and her book L'evento Auschwitz: Nella teoria politica di Hanna Arendt (Helzel 2001). The coinage of the term das Ereignis Auschwitz ("the Auschwitz event"), however, goes back to Dan Diner and Zivilisationsbruch: Denken nach Auschwitz (Diner 1988, 7). The Zivilisationsbruch ("rupture of civilization") marked by Auschwitz is here related to the Shoah in general (9).

Since it is not explicit whether Cavarero is referencing Auschwitz as a particular camp or "Auschwitz" as a synecdoche for the Shoah, I will try to refute both possible interpretations in the following. Nevertheless, I do not contest Cavarero's description of the production of the Muselmann in the death camps. Cavarero's concentration on the methodically applied process of turning prisoners with the help of various techniques into totally helpless but no longer vulnerable beings, thus destroying the ontological material that makes them unique, is striking and persuasive. But I doubt that the production of the Muselmann can be seen as the true purpose of Auschwitz. As I will argue, the Muselmann constitutes neither the singularity of this particular Nazi Lager nor the uniqueness of the Shoah. In fact, Cavarero's interpretation tends to conceal the functioning and purpose of Nazi death camps in general and of Auschwitz in particular.

First, the Muselmann was not a phenomenon confined to the Auschwitz Lager system. Similar cases existed in other camps-concentration and extermination camps alike-which were referred to as Gamel ("rotting") in Majdanek, Kretiner ("cretins") in Dachau, Krüppel ("cripple") in Stutthoff, Schwimmer ("swimmer") in Mauthausen, Kamele ("camel") in Neuengamme, müde Scheichs ("tired sheikhs") in Buchenwald, and as Muselweiber ("Muslim women") or Schmuckstücke ("pieces of jewelry") in the women's camp Ravensbrück (Sofsky 1990, 532, n. 18).

The point that the Muselmann phenomenon did not appear exclusively in Auschwitz still holds true when "Auschwitz" is interpreted in the context of Cavarero's use of it as synecdoche for the Shoah. It is important to note that such a figure of the totally emaciated inmate, reduced to a skeleton because of the terrible conditions of detention, also appears in the Gulag system of the Soviet Union. These prisoners of the Gulag were most commonly called dochodjaga ("goners" or "soon-to-be-dead"), sometimes "fitili, or 'wicks,' as in the wick of a candle, soon to be blown out..., gavnoedy 'shit-eaters' or pomoechniki 'slop-swillers"” (Applebaum 2010, 18). Like the Muselmänner, they were "prisoners at the end of the road who were now nothing but human wrecks" (Lewin 2005, 119). Natasci Mattucci therefore emphasizes correctly that "[d]ochodjaga and muselmänner represent the peculiarity 
of the totalitarian camp" (Mattucci 2015, 52). What this implies, however, is that the Muselmann cannot be understood as the phenomenon that explains the unique status of Auschwitz or the Shoah. The Muselmann is thus rather a "totalitarian" phenomenon.

Furthermore, the Muselmann is not even the typical example of Auschwitz. This becomes evident in regard to the numerical proportions of the different victim groups of this concentration and death camp. The estimated number of Jewish victims who were killed systematically during the Shoah is between 5 and 6 million. According to Wolfgang Benz, at least 5.29 million up to around 6 million Jews of every age were murdered (Benz 1991, 17), whereas Raul Hilberg counts 5.1 million dead (Hilberg 2003, 1320-21). Nearly half of them died as a result of ghettoization and deprivation, or were shot in mass executions. In the first wave of mass shootings executed by the Einsatzgruppen ("task forces") between the summer of 1941 and the spring of 1942 alone, around 535,000 Jewish victims were murdered (Benz 1991, 17; Hilberg 2003, 1320), for example, in the massacres of Babi Yar (near Kiev) and Ponary (near Vilnius) (Benz 2010, 122-23; Glass, Heim, and Hoppe and 2011, 37-42, 81, 222-23). The extermination camps, and especially Auschwitz, nevertheless played a crucial role in the Final Solution.

Auschwitz was initially founded in May 1940 as a "transit center" (Hilberg 2001a, 32), mainly for political prisoners, but was extended over the years to become the biggest concentration- and extermination-camp system in the Third Reich, eventually composed of three main and more than forty satellite camps. The second main camp, Auschwitz-Birkenau, hence also known as Auschwitz II, was constructed in October 1941, and the third main camp, Auschwitz-Monowitz-built and financed by IG Farben to provide the workforce for the nearby industrial complex of the Buna Werke-started its operations in the same month of the following year (3435). On Polish territory, at least 2.6 to 3 million Jews were gassed in one of the six death camps, around one million of them with Zyklon B in Auschwitz-Birkenau alone (Benz 1991, 17; Hilberg 2003, 1320). Yad Vashem, the World Holocaust Remembrance Center, estimates that in Auschwitz-Birkenau all told, "more than 1,100,000 Jews, 70,000 Poles, 25,000 Sinti and Roma (Gypsies) and some 15,000 prisoners of war from the USSR and other countries were murdered" (Yad Vashem 2018) by various means like gassing, starvation, or Vernichtung durch Arbeit ("extermination through labor"). The overall number of people deported to Auschwitz is estimated to be 1.3 million (Hilberg 2001a, 44).

What makes these numbers important in the context of Cavarero's claim about the Muselmann is that most of the Jews who arrived in Auschwitz-probably more than eighty percent-were not registered but sent directly to the gas chambers (Aronson and Longerich 2001, 194; Hilberg 2003, 1036). Only a small number of Jewish deportees, those who were "'fit to work' (arbeitsfähig) and hence were processed as inmates rather than sent to their immediate deaths" (Greif 2001, 236), were officially registered. Other groups of deportees usually "did not go through the selection process; non-Jews went on to become registered prisoners" (Gutman 1998, 31). Until the liberation of Auschwitz on January 27, 1945, all told 400,000 Jewish and non-Jewish deportees were counted as official inmates. Half of them were transferred to other concentration and death camps, whereas the other half died in Auschwitz, either in direct consequence of the dreadful conditions of detention itself, or because they were sent to the gas chambers at a later point (Hilberg 2001a, 44).

The probability of someone falling into the state of a Muselmann was, once inside the camp, quite high. Four out of five internees eventually suffered from this state 
(Wollheim Memorial n.d.). The Muselmann is therefore a typical trait of Auschwitz prisoners, but-and this is my main point-not the core of Auschwitz itself. What I want to stress is that Jewish deportees, once they arrived in Auschwitz, had such a short life expectancy that most of them did not even become internees, let alone Muselmänner: they were gassed, often immediately after the selection process, within two hours (Rawson 2015, 75). In light of these facts it is untenable to claim that the Muselmann represents the core of Auschwitz, unless the immediate gassing of 900,000 Jews is understood as nonhorroristic violence, therefore not constituting an integral component of the horror of this Nazi Lager.

Nor is the Muselmann the central figure of the Shoah in general. This becomes evident in regard to the other death camps. Next to Auschwitz-Birkenau, five other death camps existed on occupied Polish territory: Belzec, Chelmno, Sobibor, Majdanek, and Treblinka. In Treblinka alone, "some 750,000-800,000 Jews from central Poland, Germany, Austria, Czechoslovakia, the Netherlands, Belgium, and Greece were killed by gassing" (Baumel-Schwartz 2001, 179). Except for Majdanik, these were pure extermination camps, with only a small cohort of mostly Jewish interim prisoners called Sonderkommandos ("special units"), who were forced to take part in the several steps of the extermination process, like cleaning the gas chambers and crematoria, or burying the almost exclusively Jewish victims in mass graves (176). Accordingly, in The Origins of Totalitarianism, Arendt herself writes the following in reference to films that the Allies made after the end of the war to confront the German population with the massacres carried out in the concentration camps:

It is of some importance to realize that all pictures of concentration camps are misleading insofar as they show the camps in their last stages, at the moment the Allied troops marched in. There were no death camps in Germany proper, and at that point all extermination equipment had already been dismantled. On the other hand, what provoked the outrage of the Allies most and what gives the films their special horror-namely, the sight of the human skeletons-was not at all typical for the German concentration camps; extermination was handled systematically by gas, not by starvation. (Arendt 1979, 446, n. 138; emphasis added $)^{4}$

Arendt's quote about the German concentration camps exemplifies that malnutrition as one of the prerequisites of the production of the Muselmann-although part of unbearable daily life in a concentration camp-was one but not the main method of the destruction of the European Jews and of other detainees, let alone the actual core of Auschwitz. Consequently, one can find certain phenomena, like the Muselmann, that parallel other genocides or camp systems. However, as I will demonstrate, the "Auschwitz event" has characteristics that are unprecedented and that call for the thesis that Auschwitz is singular.

Cavarero's concentration on the fabrication of the Muselmann leads, as shown above, to the conclusion that the decisive factor for explaining the horror of Auschwitz is the perversely helpless but no longer vulnerable-and therefore totally dehumanized-being. This claim is invalid in view of the given historical facts. What is missing in this characterization of the horror is the intended and almost fully accomplished methodical, planned, and in large part industrially organized mass extermination of an entire people at an unprecedented scope. Already the sheer numbers show that the main purpose of the extermination camps was the destruction of the 
European Jews. Nonetheless, I agree with Arendt that this quantitative fact does not constitute "Auschwitz" as a unicum (Arendt 1979, 458-59). In other words, the mere quantity, combined with the argument about the occurrence of the Muselmann in the Gulag system, depicts a historical reality that refutes Cavarero's main claim about the purpose of Auschwitz. However, these numbers do not explain-and this is important in order to avoid misunderstandings-why Auschwitz is unique. Accordingly, one has to ask: What then constitutes its singularity? What are the qualitative features that made the Shoah unique?

\section{Why Auschwitz is Singular}

In order to answer the question of the uniqueness of Auschwitz, it is essential to understand that this question does not necessarily exclude the possibility of a historical comparison. As Alan Rosenberg points out, different positions regarding the singularity thesis can be identified in Holocaust scholarship (Rosenberg 1987, 146-47). Rosenberg differentiates three groups: First, the "trivialists" who downplay the singular character of the Shoah by pointing out that history does not repeat itself and that every historical phenomenon is therefore always unique. Often with recourse to other mass atrocities, like the Armenian genocide, the "trivialists" do not simply maintain comparability, but tend to claim similarity, if not equivalence. Consequently, the Shoah can "be regarded as just one more incident—albeit a flagrant one-of man's inhumanity to man, one more horrible atrocity in a century filled with them" (150).

At first, Cavarero herself seems to lean toward this very position when she characterizes the extermination camps as "the apex of horrorism" (Cavarero 2009, 33) and problematizes that the singularity thesis is "taken for granted in almost all the literature on totalitarian horror" (45). She is not explicitly rejecting this thesis, although she seems to be critical of it when she notes that some scholars even "trac[e] [the Auschwitz event] back to a substantial ineffability," thereby "attributing to it a Satanic grandeur and thus sacralizing it" (46). At the same time, Cavarero claims that "every attempt to make sense of its horror runs into a limit of explicability" (Cavarero 2018, 130). This seems rather paradoxical since, as Cavarero herself argues, the claim of such a limit carries the risk of a sacralization of the phenomenon under scrutiny.

This paradoxical argument for a limit, however, points to a second group of Holocaust scholars, who directly oppose the trivialist position. What Rosenberg coins the "absolutists" is a group of scholars who argue that the Shoah is not understandable at all and that "[i]ts singularity is such that it exceeds the power of language to express; its meaning is such that it belongs to 'another planet" (Rosenberg 1987, 151). According to this position, the singularity of the Shoah forbids not only any comparison, but also any (historical) explanation.

The third group, in which Rosenberg positions himself and to which I would assign myself as well, can be called "contextualists" (151). Here the claim is "that the Holocaust must be viewed contextually" and that it is thus not absolutely but "relatively unique" (51), meaning a uniqueness that can be determined only through a historical comparison to other genocides and, consequently, through the identification of qualitative, "unique" factors resulting from it: "Approached from this angle the Holocaust is neither 'extra-historical,' in the sense claimed by the absolutists, nor yet just another atrocity, as the trivialists maintain" (151).

A historical analysis is thus paramount, but not as an end in itself. Only a historical analysis can work out that "Auschwitz" had specific causes and characteristics that 
make it unique and that therefore have to be fought in a specific way, based on the analysis of these causes and characteristics. At the same time, one must avoid the danger of making the singularity absolute, as Cavarero has correctly pointed out as well, because "if we fail in our efforts at historical comprehension, and if our social theories are inadequate to the task of explaining such events, we are almost sure to experience similar catastrophes in the future" (Rosenberg 1987, 151). In other words, if Adorno's dictum-"that Auschwitz should never happen again"-is to become reality, a historical account is a prerequisite in order to prevent and fight the unique causes and characteristics of the "Auschwitz event."

So what makes Auschwitz unique? To understand the singularity of "Auschwitz," two qualitative points are important, which I can indicate only briefly in the following. These two points are intrinsically linked to anti-Semitism: First, the mass extermination of the European Jews is connected to a fundamental assumption that results from the logic of the so-called Vernichtungsantisemitismus or "eliminationist anti-Semitism" (Goldhagen 2001, 2), namely that the Jews in their entirety had to be eliminated at all costs (intentionality thesis). This fundamental assumption goes together, as I will outline, with three other aspects that are constitutive for eliminationist anti-Semitism, namely the absence of any external motive, the delusion of the enormous power of the Jews, and the global scope of the planned extermination. The second qualitative point that makes the Shoah singular is the systematic, planned, and in large part industrially organized way of extermination that separates it from other cases of mass atrocity (methodology thesis). ${ }^{5}$

The ideology of National Socialism is composed of several elements and cannot be reduced to a single one (Weinstein 1980, 117), although different forms of anti-Semitism played, as Shulamit Volkov argues, a key part in the "cultural code" (Volkov 1978, 34) of Germany from the end of the nineteenth century on. In relation to the Shoah, however, a specific German form of anti-Semitism-exterminationist anti-Semitism-has to be understood as the decisive determinant (Goldhagen 2001, 2). ${ }^{6}$ In this form of anti-Semitism, antimodern, antiliberal, and culturally pessimistic ideas are intertwined in a way that "the" Jews appear as a personified symbol of the modern world and all its distortions. Thus, the "happiness" of the world depends on the annihilation of the Jews.

Apparently, belief in a Rassenkampf ("race war"), in a fight for racial survival, guided not only the mass extermination, but also the campaigns of destruction and wars of aggression that were inherent to the idea of the Lebensraum im Osten ("Lebensraum in the East"). However, what distinguishes the Shoah from the genocidal violence against, for example, the Poles and the Russians is the absence of any goal other than the extermination itself, as Postone argues: "Indeed, the Jews were not exterminated for any manifest 'extrinsic' goal. The extermination of the Jews was not only to have been total, but was its own goal-extermination for the sake of exterminationa goal that acquired absolute priority" (Postone 1986, 304). In the case of the Shoah, a reason other than the anti-Semitic vision of total extermination, like the motive to gain land or to exploit the population as forced labor, was missing. Thus, the extermination cannot be attributed to a (conscious or unconscious) political, economic, or military rationality outside of itself; indeed, the extermination was often directly opposed to these logics.

Moreover, exterminationist anti-Semitism in particular but also anti-Semitism in general have to be distinguished from the numerous forms of racism(s). Whereas nearly all racist worldviews "attribute potential power to the Other" (304; emphasis added), for 
instance, in sexual or material form, anti-Semitism in general imagines the power of the Jews as real and, furthermore, many times greater, therefore beyond any control (304). A further difference from racism is the asserted and generalized rootlessness of the Jews (Salzborn 2010, 93). By contrast, racialized Others are often depicted as either (too) naturally rooted in a specific territory (in the case of colonialism), or as belonging originally to another territory (as in the case of xenophobia).

What specifies exterminationist anti-Semitism in relation to the delusion of a secret worldwide Jewish conspiracy is that it is believed that this conspiracy cannot be simply shattered but has to be destroyed. In extermination lies a "promise of salvation" (Brunner 2016, 21-24), which is why Saul Friedländer characterizes this form of anti-Semitism also as "redemptive anti-Semitism" (Friedländer 2004, 83). The imagined omnipotence of the Jews leads to the necessity not only to conquer, subject, or exploit, but to exterminate once and for all every single Jewish person-whether child, adult, or the elderly-on the entire planet in order to be redeemed. Thus, the scope of the extermination is not, as in other historical cases of mass genocide, limited to a certain territory, but imagined as a project on a global scale. The National Socialist war machine, which tended to aim at a literal World War, was hence connected with the Shoah. The wars of aggression had-not only but notably-extermination of Jewish life as their goal. Accordingly, "Auschwitz" was historically and ideologically the first and only genocide that intended, and actually tried, to wipe out an entire people not only in parts of the world but from the face of the earth itself.

The intent was not only geographically but also temporally total. The extermination tried to wipe out every (cultural, social, political, architectural, traditional, and so on) memory of Jewish life as well. Death itself, usually mediated by cultural practices and traditions like a proper burial or the possibility of mourning, was in the case of Auschwitz reduced "to the indiscriminateness of biological facticity" (Udoff 2011, 341). By destroying the social fabric of Jewish life itself, not only the individuals but the generational connection- "the carrying on of life from generation to generation" (Hatley 2000, 31) - was to be dissolved deliberately. ${ }^{7}$ This is important, because the Shoah can thereby be understood not just as a future project, but as an attempt to alter the past itself. In the exterminationist anti-Semitic view, the Jews are not only supposed to exist no longer, they are supposed to have never existed in the first place. Their memory has to be totally annihilated too. ${ }^{8}$

Besides the ideological roots, what makes "Auschwitz" unique is the methodical, planned, and to a large part industrial manner in which the extermination took place. The killing of such an extreme number of deportees required a technologically refined and organizationally sophisticated procedure, which included not only the Gestapo (Geheime Staatspolizei; "secret state police"), the SS (Schutzstaffel; "protection squadron"), the SD (Sicherheitsdienst; "intelligence service of the SS"), and the Wehrmacht ("armed forces"), but also a vast number of clerks, secretaries, construction and railway workers, scientists, physicians, catering staff, and-most notably-bureaucrats (Bauman 1993, 106; Goldhagen 1996, 164-68). It is estimated that half a million people were directly involved in the various steps of the implementation of the Final Solution (Pohl 2003, 104), not to mention the tacit approval, passive acquiescence, or mere indifference of huge parts of the German population (Laqueur 2001, 198-99). The Shoah was, as Frank Bajohr and Dieter Pohl argue, an "open secret" (Pohl and Bajohr 2006, 9) in the Third Reich. According to them, even the most conservative estimates assume that at least $20-25$ million people-so at least $30-35 \%$ of the entire German population of that time-knew what was happening in the death factories in the East (9). Apart 
from the Shoah, it is noteworthy to recall the extent of direct involvement of the German population in acts of violence against helpless victims, as Goldhagen emphasizes: "If the men and women using and dragooning slave laborers are included (over 7.6 million in the German Reich in August 1944), then the number of Germans who perpetrated grievous crimes might run into millions" (Goldhagen 1996, 167).

As important as the involvement of large segments of the German population was that the extermination was organized like a process of production, as Wolfgang Sofsky vividly describes:

On a twenty-four-hour basis, victims were murdered, their corpses disposed of. Kommandos of prisoners collected the belongings of the dead and brought them to the sorting sites. The bodies were checked for gold teeth and thrown into mass graves or pits or burned in cremation ovens. Mass annihilation was organized on the basis of a division of labor. The process was integrated into a kind of assembly line, its stations coordinated in temporal sequence. Killing was mechanized by the installation of stationary gas chambers, into which hundreds of persons were lured and then poisoned by carbon monoxide or hydrocyanic acid fumes. The death factory was an apparatus that functioned smoothly, virtually trouble-free, working at a high capacity and speed. A death train arrived at the ramp in the morning; by the afternoon, the bodies had been burned, and the clothing brought to the storerooms. (Sofsky 2013, 259)

What therefore distinguishes Auschwitz and the other extermination camps qualitatively from, for instance, the Soviet Gulag is that the former were literal "death factories." This does not mean that other methods were not used in the Final Solution, such as extermination through work, mass shootings, ghettoization, intended starvation or illness, and so on. However, these methods are not unique to the Final Solution, but were and are used in other genocides as well. To put it another way, these other methods are a necessary condition in order to characterize the Shoah, but not a sufficient condition to understand its singularity, a point that is not intended, of course, to downplay their crucial role for the extermination of the European Jewry, but to show a qualitative difference in comparison to other genocides.

In order to explain the very singularity, a historical analysis is thus imperative. A historical account can show that the Shoah is a unicum, yet neither because of the number of victims nor-as Cavarero claims-because of the production of helpless but no longer vulnerable beings. It is singular precisely because exterminationist anti-Semitism was put into practice in a systematic and often industrialized way. The horroristic result was the elimination of two-thirds of the European Jews.

\section{The Horroristic Vision of Nazism: An Ontology of the One}

I have argued throughout this article that Cavarero's analysis of the Muselmann can forcefully bring to light a certain dimension of the horror of Auschwitz, although I reject her overall claim that the ontological crime of producing this helpless but no longer vulnerable figure constitutes the core of Auschwitz, and, moreover, makes either this particular Nazi Lager or the Shoah a unicum. What has to be integrated into the horror of Auschwitz is, as the historical arguments show, the extermination of the European Jews, which can be understood-as I will try to outline in the following short remarks-as an ontological crime on its own. ${ }^{9}$ 
The decisive factor to understand horror is, according to Cavarero, a repugnance that one witnesses when being confronted with horroristic violence. This repugnance is the effect of an ontological crime, which directly tries to alter and destroy the ontological material of unique human beings. Certainly, the figure of the Muselmann is, in contrast to the cold facts, a more vivid image of the horror of Auschwitz. However, the sheer numbers and facts of the Final Solution provoke-at least for me-a mixture of repugnance, sorrow, and anger in the presence of such inconceivable atrocities. Moreover, they suggest that the horror of Auschwitz lies in fact in "the simple mass production of corpses" (Cavarero 2009, 42) - as Cavarero describes the extermination itselfwhich is an attack on the ontological material, although not merely an act of violence against a single human being and its uniqueness. Consequently, the historical argument for the singularity of Auschwitz, especially that it is empirically and ideologically based on the goal of killing every Jewish person not only within a certain territory but on a global scale, suggests that the ontological crime that makes Auschwitz singular cannot be found in the attack on human uniqueness that Cavarero describes. Without question, the attack on human uniqueness and hence the production of the Muselmann was an important part of the reality of "Auschwitz." In this sense, both the ontological crime of the production of the Muselmann as well as the ontological crime of the planned extermination of the Jews are intertwined characteristics of the Shoah. However, it is the latter characteristic and not the former that explains its singularity, as my historically inspired comparison to the Gulag system as well as the analysis of the qualitative factors of the Final Solution have shown.

The extermination of the Jews was driven by the idea that the Germans (and Germanic people) constituted a higher race, the so-called Übermenschen ("superior human"). The delusion of being redeemed by the submission of all enemies, and, as in the case of the Jews, by the extermination of an entire people points to the fact that the Shoah is an attack against plurality itself, which is not based only in uniqueness and relationality, but which constitutes humanity as such. One goal of Nazism was the radical destruction of this plurality of humanity by eliminating entire collectives. Although the Shoah targeted precise human beings due to their (assigned) group affiliation, it poses a universal problem for humanity as a whole (Diner 1988, 9), or, at the very least, for Western modernity (Bauman 1993, 84). The horroristic vision of Nazism was therefore not aimed merely at the production of invulnerable beings, as Cavarero claims, although this constituted a part of the reality at that time. Rather the Nazis imagined something far more perverse, something that might be named an "ontology of the One": a narrowed humanity that was literally composed of "one People, one Realm, one Leader" (Ein Volk, ein Reich, ein Führer).

Thinking horror as an ontological crime that targets not only the ontological material of unique human beings, but also the ontological material of humanity as a whole can point to the sense in which the unicum of Auschwitz can be understood as horroristic. The core of Auschwitz, interpreted this way, was therefore-in line with the given historical account-an attack on the ontological condition of plurality, not in order to produce living dead, but to reduce humanity to one people alone by way of the final and irreversible extermination of those who were seen as not belonging to this one.

Acknowledgments. I thank Fanny Söderbäck for letting me participate in her seminar "Adriana Cavarero: A Philosophy in the Singular" at DePaul University. She not only made very helpful suggestions for improving my argument, but also strongly encouraged me to submit this article. A special thanks also goes to Peg Birmingham, who took the time to give me very helpful comments. I am very grateful for the 
anonymous reviewers at Hypatia and their invaluable feedback, which enabled me to refine my argument. Furthermore, I thank the participants in Söderbäck's seminar, with whom I spent many hours discussing the issues at hand, as well as Adriana Cavarero herself, who attended our seminar for one session and who dealt with our questions and objections in a very impressive, extensive, and sympathetic manner. Thanks also to Ryan Froese for some stylistic remarks. Finally, I thank Pia Berghoff, Christian Kleindienst, and Richard Ramm, all of whom offered helpful comments and conversations on the topic of the article and who have provided great personal and intellectual support for me for a very long time.

This article was written during my exchange visit as a Fulbright scholar at DePaul University, Chicago, which was generously funded by the German-American Fulbright Commission.

\section{Notes}

1 Best known in this discussion is certainly Agamben 2002, especially 41-86.

2 Further reflections on the question of sexual difference can be found especially in Cavarero's seminal text "Towards a Theory of Sexual Difference" (Cavarero 1993).

3 The original quote reads: "No analysis of National Socialism that cannot account for the extermination of European Jewry is fully adequate."

4 At the first moment, Arendt's connection between "special horror" and "the sight of the human skeletons" could be read as a limitation of horror to the Muselmann and therefore as affirmation of Cavarero's main claim that the Muselmann represents the real horror of Auschwitz. Throughout the book, however, Arendt links horror with several historical circumstances, including the Shoah. She writes, for example, that "[o]nly the horror of the final catastrophe, and even more the homelessness and uprootedness of the survivors, made the 'Jewish question' so prominent in our everyday political life" (Arendt 1979, 3; emphasis added).

5 Here I disagree with Rosenberg. For him, only the methodological view (that is, "the various processes, techniques, and methods of destruction" [Rosenberg 1987, 156]) can explain the singularity of Auschwitz. He claims accordingly that the intentionality thesis runs into a self-contradiction, because it links the singularity to the intent to annihilate the Jewish people in its entirety. For Rosenberg, however, the intent of a total extermination is characteristic of every genocide and can therefore not be the basis for the singularity thesis (154-55). Although it is true that genocidal projects aim at the total destruction of a certain (ethnic, racial, national or religious) group within a certain territory, I will argue that the anti-Semitic intention in the case of the Shoah goes beyond other genocides, since it envisions the total destruction not only within a certain territory but also on a global scale. Moreover, the intentionality thesis is fundamental to the characterization of the singularity, because otherwise it would not be possible to explain why such a methodically organized, refined killing machine was set in motion in the first place and why it outweighed other motives-such as economic rationalities or military considerations. One of the origins of the global desire for annihilation can thus be found in the anti-Semitic idea of a globally operating, extremely powerful Weltjudentum ("Judaism of the world").

6 This specific German formation does not refer to a "German national character or any kind of eternal unchanging German beliefs or qualities: merely that for peculiar historical reasons, a brand of virulent antisemitism became part of German culture" (Goldhagen 2001, 2).

7 I thank the anonymous reviewer for drawing my attention to this important point.

8 The so-called "Museum of an Extinct Race" in Prague seems to contradict this argument. It is often claimed that in August 1942 the Jewish community of Prague was commissioned by the Nazi Zentralstelle für jüdische Auswanderung (Central Office for Jewish Emigration) to establish such a museum (Veselská 2016, 41). Thus it seems as if the Nazis wanted to keep the memory of the enemy to be annihilated alive. Although it is true that the Zentralstelle allowed the Jewish community in Prague to continue operating the Jewish Museum, which had been founded in 1906 and was temporarily closed after the Nazi occupation, there is no evidence in German primary sources that a plan for a "Museum of an Extinct Race" existed (Ernst 2003, 436). Furthermore, its alleged status as a propaganda tool is highly questionable, especially because the collections of the Prague museum - which was run as a nonpublic institution limited primarily to the collection of Jewish cultural artifacts and the creation of exhibitions for Nazi officials-were put together by the Jewish staff themselves without significant intervention of the Zentralstelle. It thus represented not the Nazis' anti-Semitic view but rather the perspective of the Prague community. Likewise, 
most of the collected objects had no propaganda value (Veselská 2016, 69). According to Magda Veselská, it can thus be said that the existing Prague museum "was everything else than a potential tool for Nazi propaganda" (69). She therefore stresses correctly that "the 'museum of an extinct race' label can be seen more as a post-war construct" and that this "designation cannot be regarded as authentic, as it has no basis in the relevant documents that have been preserved" (69). In this context, it is also worth mentioning the so-called Posener Reden (Posen speeches) of October 1943, in which Heinrich Himmler, the Reichsführer of the SS, emphasized that the deeds of the SS during the Final Solution were "a glorious page never mentioned and never to be mentioned," as can be heard on the preserved recording (German recording: Bayerische Staatsbibliothek; German transcript and English translation: The Holocaust History Project 2004). In the manuscript of this speech, Himmler stated even more openly that these deeds were "an unwritten and never-to-be-written page of glory in our history" (German manuscript: International Military Tribunal Nuremberg 1948, 145; English translation: Gutmann 1999, 344); in other words, that the history of the Shoah should never be written and therefore not be exploited for propaganda purposes. A "Museum of an Extinct Race" would have been in complete contradiction to Himmler's viewpoint, although it also has to be kept in mind that within the higher Nazi ranks different, sometimes opposing perspectives existed. In light of the previous arguments, I would nevertheless claim that not only the Final Solution had to be a secret but that one of the goals of Nazi exterminationist anti-Semitism was to destroy any remembrance of the Jews once and for all.

9 In my deliberations, I have concentrated solely on the Shoah, and not on the porajmos ("the devouring"), the genocide of the Sinti and European Romani (Hilberg 2001b, 274). It is important to note, however, that the Nazis also tried to eliminate this people once and for all, and that the question of the singularity of Auschwitz has to take this genocide into account as well, although anti-Ziganism and anti-Romanyism, respectively, differ in certain respects from anti-Semitism, especially in relation to an imagined omnipotence that is not attributed to the Sinti and Romani.

\section{References}

Agamben, Giorgio. 2002. Remnants of Auschwitz: The witness and the archive. New York: Zone Books. Applebaum, Anne. 2010. Gulag: A history. New York: Anchor eBooks.

Arendt, Hannah. 1966. The origins of totalitarianism. New York: Harcourt, Brace and World.

Arendt, Hannah. 1979. The origins of totalitarianism. New ed. with added prefaces. New York: Harcourt Brace Jovanovich.

Arendt, Hannah. 1998. The human condition. Chicago: University of Chicago Press.

Aronson, Shlomo, and Peter Longerich. 2001. Final Solution: Preparation and implementation. In The Holocaust encyclopedia, ed. Judith Tydor Baumel-Schwartz and Walter Laqueur. New Haven: Yale University Press.

Bauman, Zygmunt. 1993. Modernity and the Holocaust. Ithaca, N.Y.: Cornell University Press.

Baumel-Schwartz, Judith Tydor. 2001. Extermination camps. In The Holocaust encyclopedia, ed. Judith Tydor Baumel-Schwartz and Walter Laqueur. New Haven: Yale University Press.

Bayerische Staatsbibliothek. 100(0) Schlüsseldokumente zur deutschen Geschichte im 20. Jahrhundert. Rede des Reichsführers SS bei der SS-Gruppenführertagung in Posen am 4. Oktober 1943. Tondokument. https://www.1000dokumente.de/dokumente/audio/0008_pos_001.mp3 (accessed April, 23).

Benz, Wolfgang. 1991. Einleitung. In Dimension des Völkermords: Die Zahl der jüdischen Opfer des Nationalsozialismus, ed. Wolfgang Benz. Berlin and Boston: De Gruyter.

Benz, Wolfgang. 2010. Holocaust. In Handbuch des Antisemitismus. Judenfeindschaft in Geschichte und Gegenwart. Band 3: Begriffe, Theorien, Ideologien, ed. Wolfgang Benz. Berlin: De Gruyter.

Brunner, Markus. 2016. Vom Ressentiment zum Massenwahn: Eine Einführung in die Sozialpsychologie des Antisemitismus und die Grenzen psychoanalytischer Erkenntnis. In Schiefheilungen: Zeitgenössische Betrachtungen über Antisemitismus, ed. Charlotte Busch, Martin Gehrlein, and Tom D. Uhlig. Wiesbaden: Springer Fachmedien.

Cavarero, Adriana. 1991. The need for a sexed thought. In Italian feminist thought: A reader, ed. Paola Bono and Sandra Kemp. Oxford: Basil Blackwell.

Cavarero, Adriana. 1993. Towards a theory of sexual difference. In The lonely mirror: Italian perspectives on feminist theory, ed. Sandra Kemp and Paola Bono. London and New York: Routledge. 
Cavarero, Adriana. 1995. In spite of Plato: A feminist rewriting of ancient philosophy. New York: Routledge. Cavarero, Adriana. 2002. Politicizing theory. Political Theory 30 (4): 506-532.

Cavarero, Adriana. 2005. For more than one voice: Toward a philosophy of vocal expression. Stanford: Stanford University Press.

Cavarero, Adriana. 2009. Horrorism: Naming contemporary violence. New York: Columbia University Press. Cavarero, Adriana. 2014. "A child has been born unto us": Arendt on birth. PhiloSOPHIA 4 (1): 12-30.

Cavarero, Adriana. 2016. Inclinations: A critique of rectitude. Stanford: Stanford University Press.

Cavarero, Adriana. 2018. "Destroy your sight with a new Gorgon": Mass atrocity and the phenomenology of horror. In Emotions and mass atrocity: Philosophical and theoretical explorations, ed. Thomas Brudholm and Johannes Lang. Cambridge, UK: Cambridge University Press.

Cavarero, Adriana, and Elisabetta Bertolino. 2008. Beyond ontology and sexual difference: An interview with the Italian feminist philosopher Adriana Cavarero. Differences: A Journal of Feminist Cultural Studies 19 (1): 128-67. doi:10.1215/10407391-2007-019.

Diner, Dan. 1988. Vorwort des Herausgebers. In Zivilisationsbruch: Denken nach Auschwitz, ed. Dan Diner. Frankfurt am Main: Fischer-Taschenbuch-Verlag.

Ernst, Wolfgang. 2003. Im Namen von Geschichte: Sammeln-Speichern-Er/Zählen. Infrastrukturelle Konfigurationen des deutschen Gedächtnisses. Munich: Wilhelm Fink Verlag.

Friedländer, Saul. 2004. The extermination of the European Jews in historiography: Fifty years later. In The Holocaust: Origins, implementation, aftermath, ed. Omer Bartov. London: Routledge.

Glass, Hildrun, Susanne Heim, and Bert Hoppe. 2011. Die Verfolgung und Ermordung der europäischen Juden durch das nationalsozialistische Deutschland 1933-1945: Band 7. Sowjetunion mit annektierten Gebieten I. Besetzte sowjetische Gebiete unter deutscher Militärverwaltung, Baltikum und Transnistrien. Munich: Oldenbourg.

Goldhagen, Daniel J. 1996. Hitler's willing executioners: Ordinary Germans and the Holocaust. New York: Knopf.

Goldhagen, Daniel J. 2001. Presentation on Hitler's willing executioners. In The "willing executioners"। "Ordinary men" debate, ed. United States Holocaust Memorial Museum. Washington, D.C.: United States Holocaust Memorial Museum.

Greif, Gideon. 2001. Gas chambers. In The Holocaust encyclopedia, ed. Judith Tydor Baumel-Schwartz and Walter Laqueur. New Haven: Yale University Press.

Gutman, Israel. 1998. Auschwitz: An overview. In Anatomy of the Auschwitz death camp, ed. Israel Gutman and Michael Berenbaum. Bloomington: Indiana University Press.

Gutman, Israel. 1999. From a speech by Himmler before the Senior SS Officers in Posznan, October 4, 1943: Evacuation of the Jews. In Documents on the Holocaust: Selected sources on the destruction of the Jews of Germany and Austria, Poland, and the Soviet Union, ed. Yitshak Arad, Israel Gutman, and Abraham Margaliot. 8th ed. Lincoln, London, and Jerusalem: University of Nebraska Press; Yad Vashem.

Hatley, James. 2000. Suffering witness: The quandary of responsibility after the irreparable. Albany: SUNY Press.

Helzel, Paola. 2001. L'evento Auschwitz: Nella teoria politica di Hanna Arendt. Lungro di Cosenza, Italy: Marco.

Hilberg, Raul. 2001a. Auschwitz. In The Holocaust encyclopedia, ed. Judith Tydor Baumel-Schwartz and Walter Laqueur. New Haven: Yale University Press.

Hilberg, Raul. 2001b. Gypsies. In The Holocaust encyclopedia, ed. Judith Tydor Baumel-Schwartz and Walter Laqueur. New Haven: Yale University Press.

Hilberg, Raul. 2003. The destruction of the European Jews: Volume III. New Haven: Yale University Press.

The Holocaust History Project. 2004. The complete text of the Poznan Speech. https://phdn.org/archives/ holocaust-history.org/himmler-poznan/speech-text.shtml.

International Military Tribunal Nuremberg. 1948. Document 1919 PS: Rede des Reichsführer-SS bei der SS-Gruppenführertagung in Posen am 4. Oktober 1943. In Trial of the major war criminals before the International Military Tribunal. Nuremberg 14 November 1945-1 October 1946: Volume XXlX. Official text English edition. Documents and other material in evidence. Numbers 1850-PS to 2233-PS., ed. International Military Tribunal Nuremberg. Nuremberg: International Military Tribunal.

Koselleck, Reinhart. 2004. Futures past: On the semantics of historical time. New York: Columbia University Press. 
Laqueur, Walter. 2001. The Final Solution: Public knowledge. In The Holocaust encyclopedia, ed. Judith Tydor Baumel-Schwartz and Walter Laqueur. New Haven: Yale University Press.

Levi, Primo. 1988. The drowned and the saved. New York: Summit.

Lewin, Moshe. 2005. The Soviet century. London and New York: Verso.

Mattucci, Natasci. 2015. The power of imagination: Literature of the inhuman. In Remembering the Gulag: Images and imagination, ed. Natasci Mattucci. Macerata, Italy: EUM.

Murphy, Ann V. 2011. Corporeal vulnerability and the new humanism. Hypatia 26 (3): 575-90.

Pohl, Dieter. 2003. Verfolgung und Massenmord in der NS-Zeit 1933-1945. Darmstadt: Wissenschaftliche Buchgesellschaft.

Pohl, Dieter, and Frank Bajohr. 2006. Einleitung. In Der Holocaust als offenes Geheimnis. Die Deutschen, die NS-Führung und die Alliierten, ed. Frank Bajohr and Dieter Pohl. Munich: C. H. Beck.

Postone, Moishe. 1986. Anti-Semitism and National Socialism. In Germans and Jews since the Holocaust: The changing situation in West Germany, ed. Anson Rabinbach. New York: Holmes \& Meier.

Rawson, Andrew. 2015. Auschwitz: The Nazi solution. Barnsley, UK: Pen and Sword.

Rosenberg, Alan. 1987. Was the Holocaust unique? A peculiar question? In Genocide and the modern age: Etiology and case studies of mass death, ed. Isidor Wallimann and Michael N. Dobkowski. Westport, Conn.: Greenwood Press.

Salzborn, Samuel. 2010. The politics of antisemitism. Journal for the Study of Antisemitism 2 (1): 89-114.

Söderbäck, Fanny. 2018. Natality or birth? Arendt and Cavarero on the human condition of being born. Hypatia 33 (2): 273-88.

Sofsky, Wolfgang. 1990. Absolute Macht: Zur Soziologie des Konzentrationslagers. Leviathan 18 (4): 51835.

Sofsky, Wolfgang. 2013. The death factory. In The order of terror: The concentration camp, ed. Wolfgang Sofsky. Princeton: Princeton University Press.

Udoff, Alan. 2011. On poetic dwelling: Situating Celan and the Holocaust. In Argumentum e Silentio: International Paul Celan symposium/Internationales Paul Celan-Symposium, ed. Amy D. Colin. Berlin: De Gruyter.

Veselská, Magda. 2016. "The Museum of an Extinct Race"-Fact vs. legend: A contribution to the topic of the so-called Jewish councils in Central Europe. Judaica Bohemiae 51 (2): 41-83.

Volkov, Shulamit. 1978. Antisemitism as a cultural code: Reflections on the history and historiography of Antisemitism in imperial Germany. Leo Baeck Institute Yearbook 23 (1): 25-46. doi:10.1093/leobaeck/ 23.1.25.

Weinstein, Fred. 1980. The dynamics of Nazism: Leadership, ideology and the Holocaust. Oxford: Elsevier Science.

Wollheim Memorial. N.d. Muselmänner. http://www.wollheim-memorial.de/en/muselmaenner.

Yad Vashem. 2018. Auschwitz-Birkenau extermination camp. https://www.yadvashem.org/holocaust/ about/final-solution/auschwitz.html\#narrative_info.

Leonhard Riep is a graduate student in philosophy and cultural studies at the University of Leipzig, Germany. In the academic year 2018-19, he participated in the graduate program in philosophy at DePaul University, Chicago, as a Fulbright scholar. His research interests lie in the field of political theory, cultural philosophy, and comparative and transfer-oriented cultural history, with a special focus on postcolonial and queer-theoretical perspectives as well as poststructuralist and (post-)Marxist approaches. His book Die Dimension des Politischen in der Geistigkeit: Jan Patočkas "Sorge um die Seele" und Michel Foucaults "Sorge um sich" (Nordhausen: Verlag Traugott Bautz) was recently published.

Cite this article: Riep L (2020). The Production of the Muselmann and the Singularity of Auschwitz: A Critique of Adriana Cavarero's Account of the "Auschwitz Event". Hypatia 35, 626-645. https://doi.org/ 10.1017/hyp.2020.41 